\author{
ARTICLES \\ FASCICULI ARCHAEOLOGIAE HISTORICAE XXXIV: 2021 \\ ISSN 0860-0007, e-ISSN: 2719-7069 \\ DOI 10.23858/FAH34.2021.001
}

TOMASZ KURASIŃSKI*

\title{
AGAINST DISEASE, SUFFERING, AND OTHER PLAGUES: THE MAGIC-HEALING ROLE OF THUNDERSTONES IN THE MIDDLE AGES AND MODERN TIMES
}

\begin{abstract}
Prehistoric stone objects (most often Neolithic) referred to as 'thunderstones' in the Middle Ages and modern times have been assigned various meanings - primarily they are supposed to have been used to protect against lightning, fire, and other natural disasters. They have also found application in folk medicine and healing magic (protection against the harmful effects of disease and loss of fertility, and neutralisation of misfortune when it has already occurred). Trust in their magical (apotropaic) properties was probably associated with the belief that these objects originated from outside the sphere of the 'tame' world. Folklore and ethnographic data, as well as traces of use preserved in archaeological monuments, support a long tradition of therapeutic use of thunderstones, which is a pan-European phenomenon.
\end{abstract}

Keywords: prehistoric stone products, thunderstones, magic-medical meaning, folk medicine, Middle Ages, Modern Times

Received: 19.07.2021 Revised: 10.08.2021 Accepted: 03.09.2021

Citation: Kurasiński K. 2021. Against Disease, Suffering, and Other Plagues: the Magic-healing Role of Thunderstones in the Middle Ages and Modern Times. "Fasciculi ArchaeologiaeHistoricae" 34, 7-24, DOI 10.23858/FAH34.2021.001

\section{Introduction}

In recent years archaeologists have seen an increased interest in the group of finds most often described and analysed in scientific literature under the name of 'archaica' - that is, objects made much earlier than the chronological context of their finding would indicate (in the case of an archaeological find this could be a layer, grave, treasure, or other object). There may also be other premises, such as any modifications and interference with the original structure (e.g. engraving, perforation, fragmentation), which can indicate that they were created much later than the object itself. In other words, the study of 'archaica' is about objects from the distant past and later adapted in

\footnotetext{
* Institute of Archaeology and Ethnology Polish Academy of Sciences, Łódź; (D https://orcid.org/0000-0002-8158-1104; tomasz. kurasinski@wp.pl

${ }^{1}$ This term was introduced into a wider scientific circulation by A. Mehling in a monograph on 'ancient' elements of posthumous equipment from Merovingian cemeteries (Mehling 1998). In relation to the discussed category of objects, the researcher also used other names: Altsachen, Altstücke (see Mainka-Mehling 2009; for terminology see also Knight et al. 2019, 4-5).
}

completely different cultural realities, when their real origins as products of human hands were generally no longer realised. ${ }^{2}$

Archaica are very diverse in terms of form, manufacturing technique, and the raw material used; the only common denominator is the time-distant record. ${ }^{3}$ They can be various artefacts- most often coins, elements of clothing, tools, weapons, or utensils - both those preserved in full, as well as incomplete or in small fragments. Thus, each of the identifiable categories of these items 'may have been related to different contexts of belief, symbolism and semantics, and the meaning of some of these combines numerous interrelated and

\footnotetext{
${ }^{2}$ Limiting ourselves to non-monetary finds known from the Middle Ages and modern times, see, among others, Burić 2015; Kurasiński et al. 2015; Rustoiu 2015a; Rustoiu 2015b; Farkaš and Gregor 2016; Grønbeck 2016; Søvsø et al. 2016; Johanson 2018; Labatt 2018; Menšík 2018; Musin et al. 2018; Houlbrook 2019; Knight et al. 2019; Kajkowski 2020; Kurasiński and Skóra 2020; Rapan Papeša 2020; Kurasiński 2021; Kurasiński, forthcoming; Verhart et al. 2021 extensive literature in these works.

${ }^{3}$ Ungerman 2009, 237.
} 
complementary functions and applications' ${ }^{4}$ At the most generalised level, archaica can be classified according to the way they are further used: utilitarian or non-utilitarian. Utilitarian (pragmatic) goals can be associated with conventionally understood recycling, while when it comes to possible non-utilitarian use, we enter the complex sphere of human imagination, beliefs, and mental perception of reality. ${ }^{5}$ However, one should keep the model approach to such a classification in mind, because it is not always possible to determine indisputably the function of a given find; in the interpretation one must take into account chronological, regional, and social conditions. In comprehending the reality of ancient societies, the border between what is utilitarian (profanum) and what is non-utilitarian ( $s a-$ crum) is blurred. Both orders interpenetrate and remain in constant interaction, so that even everyday (technical-utilitarian) activities can take on a sacred character. As research shows, there is a continuum of practices in traditional cultures, ranging from formal and highly ritualised events to small-scale, informal routine activities (such as discarding refuse). ${ }^{6}$

\section{Healing magic in general}

In each area of human activity (spiritual and material), the presence of ritualistic and magical activities is more or less visible. For obvious reasons, in this work it is impossible to comprehensively address the cultural and social functioning of magic and its connections with religion and science. What is important for this work is the practical direction of magic in interaction with supernatural forces. According to some views (antimentalist theories), 'magical activities' were those focused on the intended effectiveness of a specific action and were a 'technical' means to achieve the intended end. ${ }^{7}$ In this sense, magic can be defined as 'methods that somehow interface with the supernatural and by which people can bring about particular outcomes' ${ }^{8}$

This rational element is particularly effective in healing and protective magic. Due to the biological dimension of living creatures, it was supposed to provide protection against any deviations from health norms, both somatic and psychological. ${ }^{9}$

${ }^{4}$ Kurasiński and Skóra 2020, 302.

${ }^{5}$ See Kurasiński and Skóra 2020, 333.

${ }^{6}$ Cf. Chadwick 2012 . As accurately stated by P. Zając: 'Everyday life is also a ritual, but unaware of its apotropaic and ordering function' (Zając 2003, 95; see also Kędzierzawski 2009, 31).

${ }^{7}$ Malinowski 1990, 440, 442; Kieckhefer 2001, 35.

${ }^{8}$ Stein and Stein 2010, 136.

${ }^{9}$ Swienko 1981, 141, 171. At this point, the division of etiological beliefs and remedies of medical practices into 'rational' and 'irrational,' dating back to the positivist ethnography of the 19th century, should be denied. According to D. Penkala-Gawęcka,
With disease and plagues, as with any other misfortune, people tried to fight with all available means and methods, both verbal (spells, incantation) and nonverbal (gestures, behaviour)..$^{10}$ Therapeutic treatments used in the traditional treatment of humans, animals, and even plants were derived to the same extent from beliefs, practical activities and knowledge passed down from generation to generation. ${ }^{11}$

In folk consciousness permeated by religious and magical categories, belief attributing the origin of disease to the interference of a personal factor (e.g. an ancestor, an evil spirit, a deity, or a human (witch or sorcerer), as exemplified by charms and spells, was widespread. In the concept proposed by G. M. Foster, it is characteristic of personalistic ethology, which in explaining the appearance of the disease emphasises the purposeful and active participation of a personal agent. In personalistic terms, the sick person is a victim, the object of aggression or punishment specifically directed against him, for reasons that concern him alone. ${ }^{12}$ And disease is only one specific case in the explanation of all misfortune caused by the same deities, spirits, or witches. The participation of healers with supernatural or magical skills is required to ward it off. ${ }^{13}$

'from the anthropological perspective, each method of treatment, the use of each medicine can be considered rational, if, in the opinion of the studied group, according to its knowledge system, it leads to the desired results' (Penkala-Gawęcka 1994b, 18; on this topic see also Penkala-Gawęcka 1995, 178-180).

${ }^{10}$ See Walęciuk-Dejneka 2005; Marczewska 2012; Domańska 2016; Marczewska 2019

${ }^{11}$ It is worth adding that the limited degree of differentiation of individual spheres of folk culture results in difficulties in establishing the scope of the concept of 'folk medicine.' For there is no 'clear distinction between medical and mythological knowledge, therapeutic practices and magical-ritualistic activities, and the same practices may be assigned non-therapeutic values; disease is not separated from many negative phenomena; health and illness are individual problems, but also social and cultural problems, they are related to other cultural problems to explain the meaning of suffering, death, etc. This syncretism also implies that the same object, the same activity can be interpreted in various ways' (Jaguś 2001, 176-177).

${ }^{12}$ In studies of folk medicine, attention is paid to the external origin of the disease, which is primarily the result of the actions of demons and sorcerers, as well as the divine will, in a situation of violation of morality (Musiatewicz 2003, 179-180; Marczewska 2012, 81-90). The perception of the disease as a punishment for violating social norms (inappropriate sexual behaviour, perjury), which are within the competence of specific deities, is already confirmed in the source for the religiosity of pre-Christian Slavs (Szczepanik 2016).

${ }^{13}$ The origin of the disease is explained differently by naturalistic ethology, which perceives it in impersonal terms. The ailments do not result from the activity of an angry being, but from natural forces or conditions such as cold, heat, wind, dampness, and above all, from imbalance of the humours. Of course, not all observations can be easily classified, especially when it comes to 
Due to this supposed origin of the disease, prophylaxis and therapy were carried out as part of religious rituals and magical treatments (protective as well as cleansing and preventive). As emphasised by M. Marczewska, in traditional communities 'linking healing activities with magic is a characteristic feature of human activities associated with treatment and getting rid of disease. ${ }^{14}$ Magic and religion were used particularly intensively during epidemics and natural disasters, which were viewed as punishments for moral failure and sin. The set of specific views on the source of the disease brought to life adequate healing practices. Among them, we can distinguish prophylactic treatments, the purpose of which was to ward off illnesses and charms, as well as therapeutic treatments, focusing on driving out a disease already present in the body. ${ }^{15}$ The time and space circumstances in which the act of healing or preventing the disease took place played an important role. One condition for the success of the treatment was conducting it at a favourable moment - during so-called auspicious hours, moon phases, or a religious holiday. ${ }^{16}$ In an effort to preserve or restore health, products of plant and animal origin, as well as other objects, often acting as apotropaia, were used. ${ }^{17}$

The confirmation of the above findings seems to be prehistoric(usually Neolithic) objects made of stone, known from numerous discoveries from the Middle Ages and modern times, ${ }^{18}$ although in the case of archaeological monuments we are usually deprived of the possibility of grasping many semantic aspects. First of all, ethnographic observations (which should be treated as an open cognitive area) come to the rescue, broadening the possibilities of interpretation and constituting a starting point for the formulation of new hypotheses about the discovered material remains. ${ }^{19}$

diseases caused by emotional disorders (for details on the criteria of the described division, see Foster 1976). The usefulness of Foster's etiological classification was noticed and used in later ethnomedical research (Penkala-Gawęcka 1994a, 7; with comments from Jeszke 1993, 99).

${ }^{14}$ Marczewska 2012, 42.

${ }^{15}$ Swienko $1981,174$.

${ }^{16}$ Górny 1996.

${ }^{17}$ In general, on the importance and nature of apotropaic measures, see Dynin 2013.

${ }^{18}$ For a summary review of the finds, see Kurasiński 2021, 7-28.

${ }^{19}$ We are guided here by the findings of A. Gazin-Schwartz, according to which folklore can provide valuable data for understanding the ritual use of artefacts, giving the possibility of a more comprehensive recognition of the complex relationships between material culture, ritual, and everyday life (Gazin-Schwartz 2001; more on the usefulness of folklore for archaeological interpretation see Gazin-Schwartz and Holtorf 2005; cf. Rajewski 2006).

\section{Protective and magic-healing properties of thunderstones}

According to most popular folk beliefs in Europe, the stone objects known as 'thunderstones' fell from the sky in the form of or accompanied by lightning and penetrated into the ground, and later shifted to the surface where they could be found. Because of this origin story they are referred to as 'thunderstones' (with many semantic and synonymous equivalents). They were considered a heavenly weapon in the hands of thunder deities (e.g. Thor, Perun) and after the spread of Christianity, of God and the saints, directed against evil powers. The myths related to this motif could, therefore, significantly fuelled and supported belief in the heavenly origin of thunderstones which were equated with discovered prehistoric objects. This was reflected in folk rituals, especially Slavic and Scandinavian. ${ }^{20}$

To those who found them, thunderstones appeared as unusual creations, to be used primarily for magical protection against lightning, fire, and other natural disasters. Hence, the objects under consideration were discovered in various places of residential and farm buildings, and even religious buildings (mainly in walls, basements, and chimneys, as well as under floors and thresholds, in foundations, and on roofs). ${ }^{21}$ Sometimes they were placed in bridges and defensive walls, as well as in wells, graves, treasures, under communication routes, and by water courses. ${ }^{22}$ Thunderstones also had many other uses, being, i.a. a structural component of medieval and modern ceremonial weapons. ${ }^{23}$ They were also widely used to improve fertility and fertility, and were also used in the treatment of humans and animals and the prevention of disease, which we will discuss in more detail in this article. ${ }^{24}$

${ }^{20}$ For more on this, see Kurasiński 2021, 29-30. In the perception of the world dominated by magical-religious thinking, myth being a model and explanatory element for all rituals and everyday activities, it legitimises magic, being the motivation and justification for it. Therefore, it can be said that mythology serves to strengthen confidence in magic (Kłonkowska 2006, 242-243).

${ }^{21}$ It is suspected that in every home in northern Europe during Middle Ages and Modern Period there was an axe or other ancient tool that was kept to ward off a catastrophe (Verhart 2015, 84). Similar opinions were expressed in relation to the area of Slovakia (Klecanda 1901, 214), Moravia (Koudelka 1882, 159), Germany (Andree 1889, 32), France (Cartailhac 1878, 19) and Spain (Pedrosa 2009, 261). This seems to be common for most regions of the European continent, especially rural areas.

${ }^{22}$ Kurasiński 2021, 28.

${ }^{23}$ Kurasiński, forthcoming.

${ }^{24} \mathrm{We}$ exclude items made of flint, especially arrowheads and spearheads, although it is known that they occurred in similar contexts as ancient stone products and were related to them in terms of meaning (e.g. Sedova 1957; Hall 2005; van Eijk 2007; Watte and Jullien 2007). We rely on research, the results of which have been presented elsewhere (Kurasiński 2021). 
The widely documented fact of using prehistoric stone products in folk medicine has found expression in the nomenclature. In South Bohemia, these items were called 'healing stones' (lékujici kameny). ${ }^{25}$ The collected data show that in the nineteenth and first decades of the twentieth century in Latvia, a wide range of prehistoric artefacts, including ones made of stone, were in the possession of sorceresses and folk healers. ${ }^{26}$ In the town of Żerniki near Gliwice in Silesia in the years 1925-1927, a local diviner used a Neolithic axe for medical purposes. The object was found by his great-grandfather in the roots of a tree that had been struck by lightning. ${ }^{27}$ There are ample grounds to see helpers of saints and God who wields lightning. It is not surprising, therefore, their ability to use thunderstones to heal disease and fight evil. ${ }^{28}$

It should be emphasised that there are various ways of using the objects in question as a therapeutic measure. Particular value was assigned to the powder scraped off the object. According to reports, this form of medicine was widely used in traditional European medicine. Such a powder, in combination with water, alcohol, or vinegar, was administered orally for various ailments, including jaundice, fever, cramps, abdominal pain, eye disorders, and childhood diseases. ${ }^{29}$ Wounds were also sprinkled with it. ${ }^{30}$ Sometimes it was enough for the thunderstone to be in the water or other liquid for a while. In Cornwall, at the end of the $19^{\text {th }}$ century, the water in which such a stone tool had been boiled was administered as a remedy for rheumatism. ${ }^{31}$ In the area of Lake Kenozero (northern Russia), in the event of stabbing in the side, water that had been poured over the object was given to the patient to drink. ${ }^{32}$

In general, however, thunderstones (when cold or warmed up) were applied, touched and rubbed on the ailing parts of the body, often assisted by uttering spells. In this way, efforts were made to get rid of, i.a. inflammations, motor complications, cysts, swellings, goitre and

\footnotetext{
${ }^{25}$ Fröhlich 1992, 239; Sklenáŕ 1999, 45. It is worth noting that in the past many categories of 'pharmaceutical stones' appearing in the form of rocks, minerals, and fossils were known in the past, see e.g. Quintía Pereira 2009; Duffin and Pymm 2015a; Duffin and Pymm 2015b; Pymm 2017; Pymm 2020.

${ }^{26}$ Vasks 2003, 30.

${ }^{27}$ Horoszkiewicz 1950, 160.

${ }^{28}$ Libera 2003, 199-200.

${ }^{29}$ E.g. Koudelka 1882, 160; Biegeleisen 1929, 343, 344; Skutil 1932, 44; Olbrich 1987, 328; Ramminger 2007, 12; Šimek 2010, 141-142; Wdowiak and Wysokiński 2013, 537-538; Barnaś-Baran 2018, 19.

${ }^{30}$ Tolstoy 1995, 562; Muhonen 2006, 8.

${ }^{31}$ Evans 1897, 56-57; Penney 1976, 72; Merrifield 1987, 13.

${ }^{32}$ Shevelev 2005, 2.
}

many skin diseases, as well as relieve any pain..$^{33}$ In order to avoid rheumatic diseases in some parts of Spain, e.g. in the province of Salamanca, it was recommended to rub the joints with them. ${ }^{34}$ We have such a recommendation also certified for Lower Silesia. ${ }^{35}$

In Limburg, until the $19^{\text {th }}$ century, thunderstones were sewn into cloth bags and carried over the chest, in the hope that they would help heal stomach ailments. ${ }^{36}$ In Scotland, it was believed that a Neolithic perforated jade axe from a belt treated kidney ailments. ${ }^{37}$ There is information that in the 1860s for this reason one such axe (of the Altenstadt type) became the property of a Scottish officer. This specimen was provided with holes at the ends and inserted into a silver binding so that it could be worn like a sporran (a fur or leather bag which is part of a Scottish ceremonial dress) (Fig. 1).$^{38}$ There are known cases of using jade axes to treat this kind of ailment in French villages as well, e.g. in the department of Gironde ${ }^{39} \mathrm{~A}$ jade axe brought from Turkey around 1670 by the French ambassador and presented to Prince François de Lorraine, bishop of Verdun, was also intended to help with kidney diseases. ${ }^{40}$

It should be mentioned here that Lapis Ceraunius (ancient stone artefacts) were used in early modern pharmaceuticals next to Lapis Lyncis (lynx stones, or belemnites), most often to cure kidney and gallstone disease. The imagined effect of such medicines prepared from thunderstones was to 'crush' and 'break' the cause of suffering (e.g. kidney stones). ${ }^{41}$ The obtained powder appears in official pharmacopoeias, e.g. in the Prussian DispensatoriumBorusso-Brandenburgicum (1698), where a high price was set for its sale..$^{42}$ The high medical importance attributed to prehistoric objects could be the reason why such items were in the collections of the Linck family of pharmacists from Leipzig (Fig. 2). ${ }^{43}$

${ }^{33}$ E.g. Lovisato 1878, 504; Koudelka 1882, 160; Palliardi 1889; Skutil 1932, 43-44; Kaufmann 1936, 34; Horoszkiewicz 1950, 160; Olbrich 1987, 328; Plessingerová and Vařeka 1999, 211; Sklenáŕ 1999, 46-49; Hála 2016a, 49-50. In Transylvania (Drăguş), they were used as a cure for the paralysis of limbs caused by mythical creatures called iele. The sick person had to be bathed in water filtered through stone axes. It should be done by old women before dawn (Ofrim 2019, 99). For therapeutic purposes, tree fragments believed to have been struck by lightning were also used, to help with rabies and especially to relieve toothache (Skutil 1932, 40; Hložek et al. 2015, 274; Hála 2016a, 52-53).

${ }^{34}$ Pedrosa 2009, 268; Rúa Aller and García Armesto 2010, 66.

${ }^{35}$ Horoszkiewicz 1950, 160.

${ }^{36}$ Verhart et al. 2021, 9.

${ }^{37}$ Penney 1976, 72.

${ }^{38}$ Sheridan et al. 2011, 8-9, Fig. 8.

${ }^{39}$ Saintyves 1936, 173-174.

${ }^{40}$ Cartailhac 1878, 31-32; Evans 1897, 59; Saintyves 1936, 98; Sklenáŕ 1999, 33.

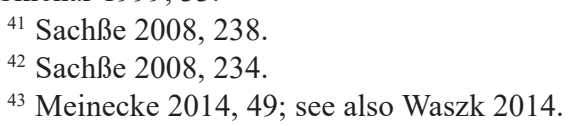




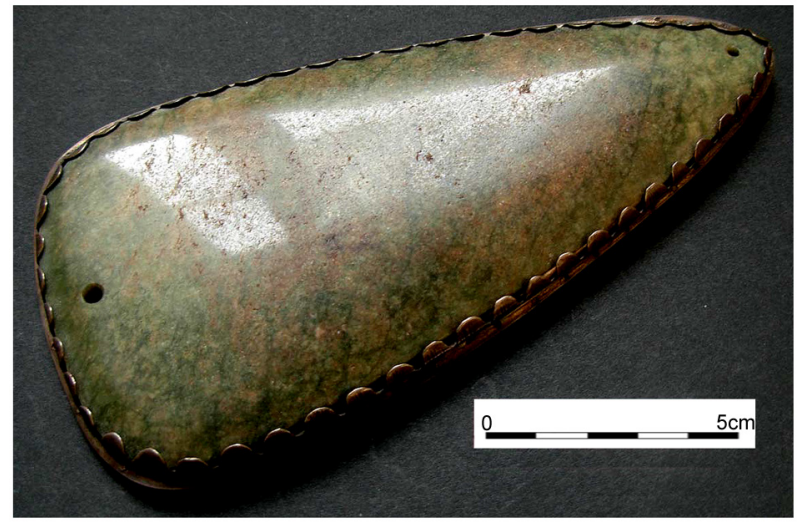

Fig. 1. A jade axe-head from Scotland said toheal kidneys. After Sheridan et al. 2011, Fig. 8.

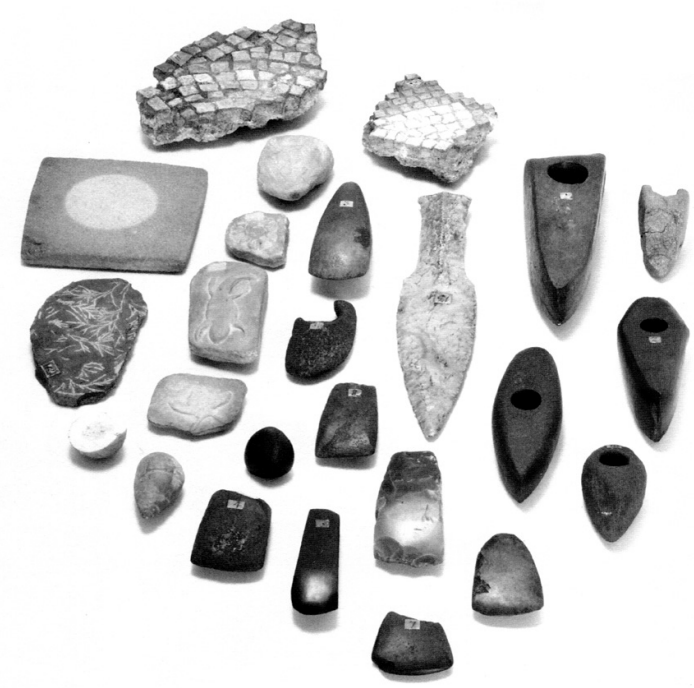

Fig. 2. Prehistoric stone products from the collections of the Linck family of pharmacists from Leipzig.

After Waszk 2014. Digitally processed by T. Kurasiński.

Ceraunia (thunderstones) were also used, i.a. against fever and in healing wounds and hernias (in this case, as a compression element of hernia bands). ${ }^{44}$ In Spain (especially in Galicia, Asturias and León) they were also believed to help with snake bites and other poisonous animals. ${ }^{45}$

It is worth mentioning that by the middle of the $18^{\text {th }}$ century these finds began to disappear from lists of recommended medicaments. Although still present in many pharmacies, thunderstones as treatment was slowly becoming a thing of the past. This resulted primarily from the advancement of medical knowledge on the one hand and archaeological knowledge on

\footnotetext{
${ }^{44}$ Sachße 2008, 239-240.

${ }^{45}$ García Castro 1988, 439; Quintía Pereira 2009, 5; Rúa Aller and García Armesto 2010, 66; Aguirre Sorondo 2013, 141.
}

the other, although the correct interpretation of thunderstones did not automatically lead to the cessation of their use as a therapeutic measure. ${ }^{46}$ The belief in the healing efficacy of these items was far from being completely forgotten, ${ }^{47}$ not only in rural environments. The belief in their healing or protective properties among the social elite may also be demonstrated by the sophisticated way of storing such items. In Scotland, around 1700, a carefully decorated leather case was made, in which a jade axe of the Altenstadt type was stored. ${ }^{48}$

In many European regions (e.g. Lower Saxony, Hesse, Scotland, Sweden, Czech Republic) the items in question were handed to women in labour to facilitate childbirth ${ }^{49}$ and recovery in the postpartum period. ${ }^{50}$ Prehistoric products were also placed in children's cradles preventively or in case of illness, ${ }^{51}$ and also to protect them from storms. ${ }^{52}$ In Sweden, they were hung around the necks of feverish small children (one such specimen (from Lilla Ånhult, Småland) was published by N. E. Hammarstedt (Fig. 3:1). ${ }^{53}$

In some treatments, attention was paid to the meaning of three, which is a number that repeats very often and is used in folk medicine. It performed many magical functions, including warding off evil and intensifying the healing effect of words and gestures.$^{54}$ In Western Romania (Vlădești) it was reported that a 'stone pierced by lightning' was used to stop a nosebleed (because of the reference to the hole, we can conclude that it, was probably a stone axe). To stop the nosebleed, it was enough to pour three drops of blood through the

${ }^{46}$ Sachße 2006, 5; Sachße 2008, 241.

${ }^{47}$ Trust in the protective power of thunderstones was also long held. Even at the beginning of the Franco-Prussian war in 1870 , German soldiers frequently bought them in pharmacies in order to protect themselves from enemy missiles (Kaufmann 1936, 32; Reitinger 1976; 534; Olbrich 1987, 327; cf. Saintyves 1936, 121).

${ }^{48}$ Sheridan et al. 2011, 9-10, Fig. 9.

${ }^{49}$ In El Bierzo and Galicia (Spain), the thunderstone was tied to the left leg to facilitate childbirth; to slow down labour, it was tied to the left hand (Rúa Aller and García Armesto 2010, 66).

${ }^{50}$ Cartailhac 1878, 21; Barner 1957, 176; Penney 1976, 72; Reitinger 1976, 534; Olbrich 1987, 328; Sklenář 1999, 46. Women in puerperium were sometimes sprinkled with powder scraped from the object to restore their full strength (Hraše 1898, 83). Sometimes they were given water with powdered stone to drink, or water in which such a stone had previously been found (Moszyński 1967, 488; Plessingerová and Vařeka 1999, 211).

${ }^{51}$ E.g. Cartailhac 1878, 21; Moszyński 1967, 488; Sklenáŕ $1999,46$.

${ }^{52}$ Toeppen 1867, 42. In Denmark, unbaptised children were supplied with stone axes (Ellis Davidson 1965, 11).

${ }_{53}$ Hammarstedt 1920, 14, Fig. 11.

${ }^{54}$ Wójtowicz 2012. 


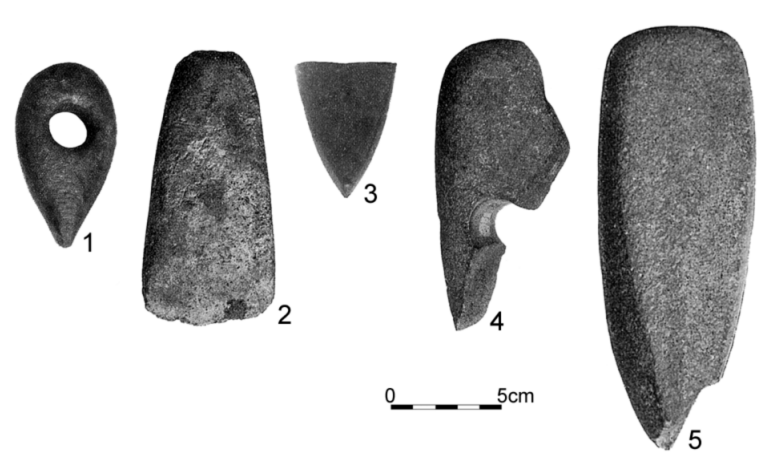

Fig. 3. Thunderstones from Sweden used in folk medicine: 1 - Lilla Ånhult. After Hammarstedt 1920, Fig. 11; 2 - Uppsala. After Hammarstedt 1920, Fig. 13; 3 - Skepptuna. After Hammarstedt 1920, Fig. 14; 4 - Ökna. After Hammarstedt 1920, Fig. 19; 5 - Boda. After Hammarstedt 1920,

Fig. 21. Digitally processed by T. Kurasiński.

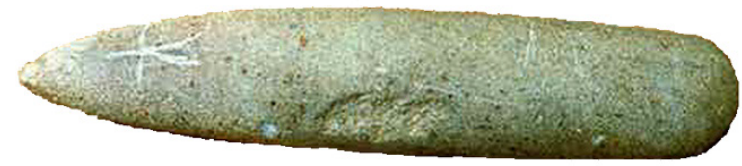

Fig. 4. Thunderstone from Vijlen (Netherlands) used in folk medicine. Fig. unscaled. After Verhart 2016, Fig. 6. Digitally processed by T. Kurasiński.

hole..$^{55}$ In Croatia, a stone arrow placed in water freed you from a spell if you drank the water three times. ${ }^{56}$

The wide range of healing and magical treatments related to stone artefacts of ancient origin also took into account the welfare of farm animals, as they were supposed to protect them against diseases as well as improve fertility and harvest.

In Germany, Czech Republic, Silesia, and Hungary, thunderstones were used to rub the sick udders of cows and goats. ${ }^{57}$ The same was done in some regions of France (Moselle) and Spain (Asturias, Huesca, León), where the thunderstones were usually previously soaked in milk, and oil was applied to the irritated udder. ${ }^{58}$ In these regions, the treatment and prevention of various ailments consisted of hanging

${ }^{55}$ Ciubotaru 2002-2003, 198.

56 Šimek 2010, 142.

${ }^{57}$ Andree 1889, 32; Kaufmann 1936, 33; Olbrich 1987, 327; Sklenář 1999, 51; Hála 2016a, 50-51; Hála 2016b, 90; Verhart 2016, 8. In some regions of present-day Poland, cow udders were also rubbed with belemnites (Jastrzębski 1996, 261), which were also commonly regarded as thunderstones that 'came from heaven' (see Kurasiński 2021, 6)

${ }^{58}$ Saintyves 1936; Blas Cortina and Maya González 1974, 213; García Castro 1988, 439; Blas Cortina and Villa Valdés 2007, 287; Pedrosa 2009, 261, 263, 265; Rúa Aller and García Armesto 2010, 65; Aguirre Sorondo 2013, 141. thunderstones on sick animals and in their pens; ${ }^{59}$ in France (Pays de la Loire), they were rubbed with fat before being placed around the neck. ${ }^{60}$ In Oldenburg and Bavarian villages, thunderstones were inserted into mangers for sick cattle, and in Pomerania and Sweden, powder was obtained from them. ${ }^{61}$ In turn, in Ireland and Northern England, because of their healing power, they were placed in troughs from which cattle were watered. ${ }^{62}$ In many European regions (for example in Hesse), water was given to calves from awaterer in which a stone axe was lying. They were also put in troughs with feed and milk for piglets. This was done with the belief that the animals would breed better. ${ }^{63}$ In Finland, on the other hand, a thunderstone placed in a waterer protected cows from lightning. ${ }^{64}$ In the highlands of France, thunderstones were boiled in water intended for sick sheep. ${ }^{65}$ From the Netherlands we have reports of thunderstones being used to relieve toothache in horses. For this purpose, a blacksmith from Vijlen applied to swollen gums an shoelast adze (Linear Pottery Culture) with the sign of the cross scratched on its surface (Fig. 4) ${ }^{66}$

Hanging the items in question in cowsheds in Spanish villages was treated as an effective stimulus for heifers to be born, which was considered more beneficial from a breeding point of view. ${ }^{67}$ In the province of León (Fresno de la Vega), the practice was noted that when horses, mares and donkeys were sheared, part of the mane was left under a thunderstone in the niche wall. This is explained by its beneficial power, which supposedly serves to protect animals or give them the strength lost due to cutting their hair. ${ }^{68}$ In the vicinity of Dinan (Brittany), axes were put into hen nests to ensure better bird brooding. ${ }^{69}$

In the past, if a cow gave milk with blood, it was milked through the hole in a stone axe. ${ }^{70}$ This practice

${ }^{59}$ García Castro 1988, 439; Rúa Aller and García Armesto 2010, 66; Aguirre Sorondo 2013, 141.

${ }^{60}$ Saintyves 1936, 126

${ }^{61}$ Cartailhac 1878, 19, 22; Olbrich 1987, 327.

${ }^{62}$ Evans 1897, 57; Merrifield 1987, 13.

${ }^{63}$ Barner 1957, 177; see also Beuker 1997, 23.

${ }^{64}$ Muhonen 2006, 9.

${ }^{65}$ Cartailhac 1878, 20.

${ }^{66}$ Hutschemakers 2008, 97; Verhart 2016, 8; Verhart et al. 2021, 9 .

${ }^{67}$ Blas Cortina and Maya González 1974, 213; Pedrosa 2009, 265, 266; Aguirre Sorondo 2013, 141.

${ }^{68}$ Rúa Aller and García Armesto 2010, 66.

${ }^{69}$ Saintyves 1936, 118.

${ }^{70}$ Toeppen 1867,42,100; Cartailhac 1878, 19-20; Bartels 1893, 559; Biegeleisen 1929, 344; Olbrich 1987, 327. In East Prussia it was believed that such an animal had spoiled milk (verhekste Milch) (Andree 1889, 32). In relation to Moravia, there is also talk of the use of thunderstones when a 'charmed' cow gave blue milk (blaue Milch) (Koudelka 1882, 160). Sometimes, as in Romania, Hungary, 
was condemned by a Lutheran pastor from Węgorzewo, the naturalist and antiquity researcher Georg Andreas Helwing, in his 1717 work Lithographia Angerburgica..$^{71}$ In Polish lands, milking through the hole in a stone axe was practiced so that cows would give a lot of high-quality milk. ${ }^{72}$ In Croatia, the urine of a sick animal was passed through the hole in this way, and incantations were uttered. ${ }^{73}$

It is worth noting that, unlike attempts to heal people, animal practices were kept secret and the content of spells was carefully guarded. The treatment of cattle was accompanied by an aura of distrust and caution. The healer was often associated with the evil powers to which he owed his abilities. ${ }^{74}$

Thunderstones were also considered an excellent protection for cultivated plants and crops. Again, it was expected to improve fertility and harvest, as well as protect against deterioration and loss of food resources necessary for survival.

In the Czech Republic, thunderstones were placed in barns to protect the grain. ${ }^{75}$ In the area of Lake Kenozero (northern Russia), stone tools were stored with turnip seeds to protect the seeds from deterioration. ${ }^{76}$ One axe from Uppsala was used in the same way (Fig. 3:2). Inserted into a sack of barley grain, it was supposed to guarantee that the resources would never run out. ${ }^{77}$ In Silesia, Sweden, and Finland, peasants put thunderstones into the store of grain seeds during so wing to obtain a good harvest. ${ }^{78}$ The custom of scattering and burying them in arable lands (Germany, Scandinavia, Czech Republic) was also widespread, on the one hand to ensure the fertility of the plants, and on the other to protect them against fires and hail. ${ }^{79}$ In some regions of France, just finding these items in the field was a promise of a good harvest and protection of crops against frost. ${ }^{80}$ For the sake of prosperity, thunderstones, especially in German-speaking regions, were hung from fruit trees,${ }^{81}$ mainly those that were sick and

Lower Silesia, or the Czech Republic $\left(18^{\text {th }}-19^{\text {th }}\right.$ centuries), such an animal had to be milked with an axe or rubbed on the udder to restore the milk lost as a result of witchcraft (Šimek 1909, 458, 459; Horoszkiewicz 1950, 160; Hála 2016a, 44; Ofrim 2019, 93-94).

${ }^{71}$ Helwing 1717, cap. VII, sectio 1, § 4, s. 85; see Abramowicz 1979, 144; Łapo 2008, 23; Szczepański 2010, 9-10.

${ }^{72}$ Biegeleisen 1929, 343.

${ }^{73}$ Šimek 2010, 141-142.

${ }^{74}$ Sklenář 1999, 50; Hložeket al. 2015, 274; see also Kaufmann 1936, 33.

${ }^{75}$ Fröhlich 1992, 240.

${ }^{76}$ Kharuzin 1894, 341.

${ }^{77}$ Hammarstedt 1920, 15, Fig. 13.

${ }^{78}$ Hammarstedt 1925, 445; Skutil 1932, 43; Olbrich 1987, 327.

${ }^{79}$ Skutil 1932,43; Sklenář 1999, 56; older literature there.

${ }^{80}$ Ribon 1993, 132.

${ }^{81}$ Boges 1910, 8; Skutil 1932, 45. withered. ${ }^{82}$ In Sweden (Värmland), stone axes were used as net weights for a more abundant catch ${ }^{83}$ and also were kept in flour in the belief that thanks to them, the food would never run out (see a fragment of a blade from the Skepptuna parish near Sigtuna (Fig. 3:3) ${ }^{84}$ In the former territories of the Old Polish Republic, thanks to a thunderstone placed in the vessel (dzieża), dough rose well and the bread was successful. ${ }^{85}$ Thunderstones were thought to protect food (e.g. milk) from deterioration, as in the case of the fragmentarily preserved axe from the parish of Ökna near Vetlanda in Sweden (Fig. 3:4) ${ }^{86}$

In addition, it is worth adding that Brittany's prehistoric stone products were often thrown into wells to purify the water or ensure its permanent presence there. ${ }^{87}$ In one Breton district (modern-day Côtes-d'Armor) it was believed that the water from such a well-protected cattle against certain diseases. ${ }^{88}$

With time, beliefs about the magical/apotropaic and healing powers of thunderstones became a thing of the past. The process was not the same everywhere and was probably localised. It seems, however, that it was not until the end of the $19^{\text {th }}$ century that faith in the objects in question was gradually eroded, although here and there its continued relict duration (especially in a traditional rural environment) should be taken into account. ${ }^{89}$ For a long time it was not realised that these were products made by man; what mattered was their 'supernatural' origin. ${ }^{90}$ Until the Industrial Revolution, it is believed that the true origin of the prehistoric artefacts remained unclear to most villagers. ${ }^{91}$ The belief in thunderstones fell from the sky and had magical powers persisted for a long time not only in folk culture, but also in the circle of learned and educated people (see Fig. 5). It was not until the end of the $17^{\text {th }}$ and $18^{\text {th }}$ centuries that science

${ }^{82}$ Olbrich 1987, 327.

${ }^{83}$ Cartailhac 1878, 21; Saintyves 1936, 228.

${ }^{84}$ Hammarstedt 1920, 15, Fig. 14.

${ }^{85}$ Biegeleisen 1929, 343.

${ }^{86}$ Hammarstedt 1920, 16-17, Fig. 19.

${ }^{87}$ Cartailhac 1878, 20; Evans 1897, 57; Saintyves 1936, 120; Merrifield 1987, 13.

${ }^{88}$ Saintyves 1936, 117.

${ }^{89}$ See e.g. Blinkenberg 1911,1,4; Muhonen 2006, 12; Johanson 2009, 163; Hukantaival 2016, 182; Kunnas-Pusa 2016, 13; Hukantaival 2019, 358-359. According to a museum note once placed next to one of the axes obtained in the Opole region (from Wróblin or Zakrzew), 'The owners were very reluctant to get rid of it in 1930 (!), because it was used for treatment until then' (Horoszkiewicz 1950, 159). Until an even later date, a Neolithic axe was used in the same way in one village of the Milicz district in Lower Silesia for about 150 years, until 1941 (Horoszkiewicz 1950, 160). The above-mentioned axe from Vijlen was used therapeutically as an analgesic at the end of the $20^{\text {th }}$ century.

${ }^{90}$ See Mehling 1998, 113.

${ }^{91}$ Verhart et al. 2021, 9. 


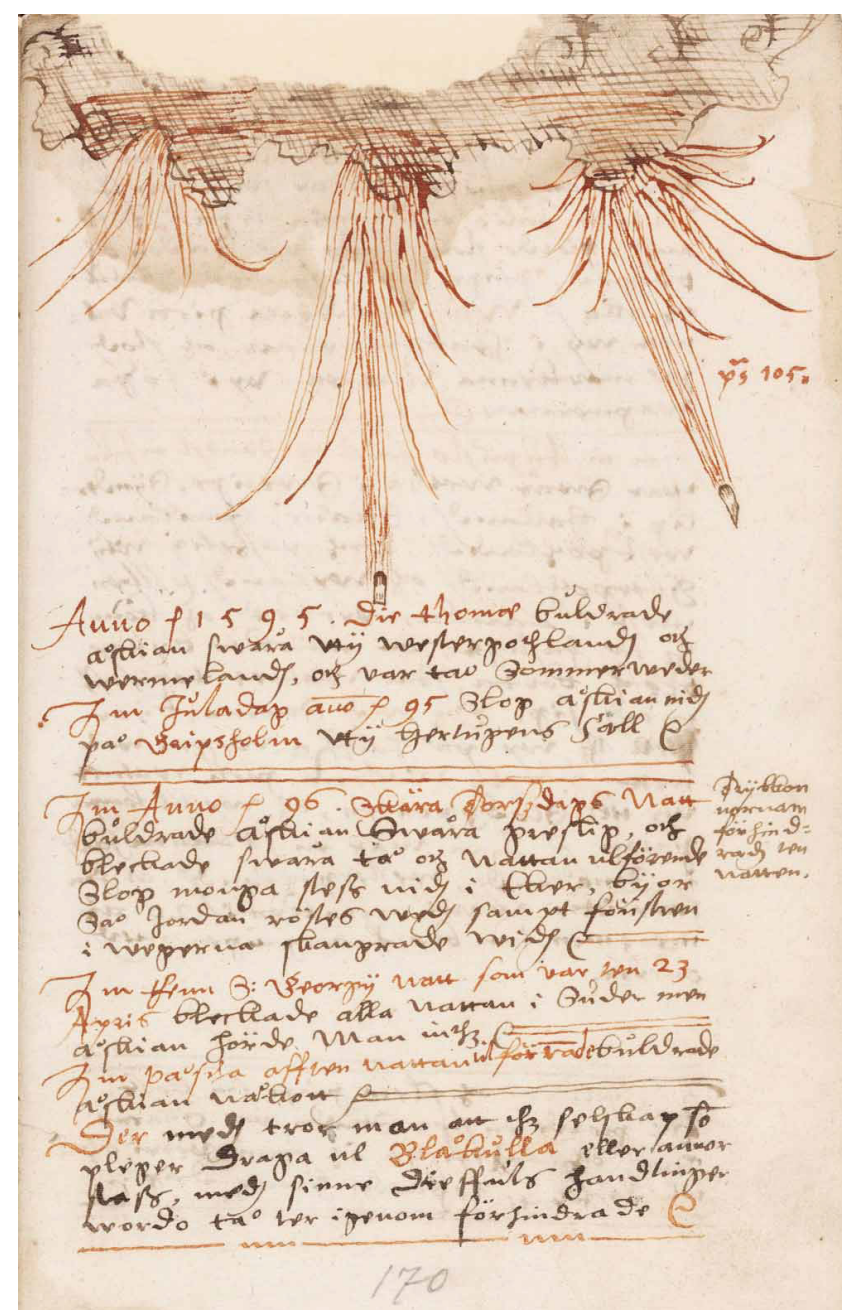

Fig. 5. Stone objects falling during a storm in the work of the Swedish pastor and chronicler J. P. Klint (†1608) Om the tekn och widunder, som föregingo thet lithurgiska owäsendet

(16 $6^{\text {th }} / 17^{\text {th }}$ century). Source: http://www.alvin-portal.org. Digitally processed by T. Kurasiński.

began to question their heavenly origins and consider them products of human hands. ${ }^{92}$ The above processes fit well with the findings of historical anthropology, according to which it was during the $17^{\text {th }}$ century in Europe the attitudes of educated people and simple people began to diverge more and more, so that at the beginning of the nineteenth century there was a final separation of high culture and popular culture, ${ }^{93}$ including scientific and folk medicine. ${ }^{94}$

\section{Possibilities of identifying thunderstones of therapeutic and apotropaic importance}

The above list of ethnographic data on the therapeutic and apotropaic use of prehistoric stone artefacts

\footnotetext{
${ }^{92}$ For an overview of the most important views, including literature, see Kurasiński 2021, 30-31.

${ }^{93}$ Burke 2009, 303-318.

${ }^{94}$ Libera 2014, 63-65.
}

raises the question of the possibility of identifying in the preserved materials (especially archaeological) specimens that were used in this way.

The powdered form of the medicine, widely used in folk medicine and veterinary medicine, had to leave traces in the form of scratches or cavities resulting from its acquisition. Mention can be made of an axe which was claimed to have fallen to the ground during a storm, found by a peasant in the Taurog region of Lithuania. The scraped-off powder from this axe was used to heal wounds, and judging by the traces for the above purpose, it was used many times. ${ }^{95}$ In 1880 , a stone axe from Boda (Småland, Sweden) was pulverised and applied to a child, as reported by N. E. Hammarstedt (Fig. 3:5). ${ }^{96}$ In turn, an axe obtained from a peasant woman near Leipzig that was kept in the former Leipziger Völksmuseums, with 'quite fresh' grooves and furrows left after the powder was collected. ${ }^{97}$ As recorded in ethnographic research, some specimens from the Opolian Silesia region that had been usedin their undamaged state for medicinal purposes could later be subjected to fragmentation procedures. ${ }^{98}$ Sometimes, however, attempts were made to restore the 'healing' axe to its original form when an undesirable fragmentation occurred, as in the case of one from the village of Łubniany, which was wrapped with wire so that it could continue to be used as a remedy for pain (Fig. 6). ${ }^{99}$

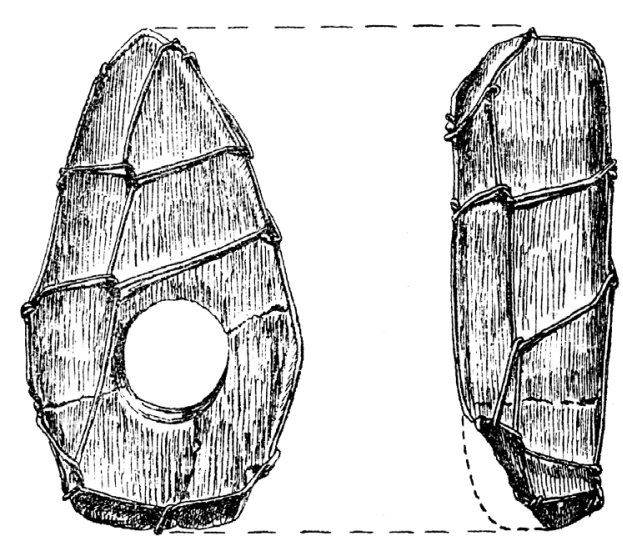

Fig. 6. Broken and reconnected healing thunderstone from Łubniany (Opolian Silesia). Fig. unscaled. After Kurtz 1928, Fig. unnumbered. Digitally processed by T. Kurasiński.

\footnotetext{
${ }^{95}$ Pokrovskiy 1899, 39.

${ }^{96}$ Hammarstedt 1920, 17, Fig. 21.

${ }^{97}$ Seyfahrt 1913, 262.

${ }^{98}$ Horoszkiewicz 1950, 159.

${ }^{99}$ Kurtz 1928, 1; Horoszkiewicz 1950, 159-160 (here erroneously as Łubiany).
} 

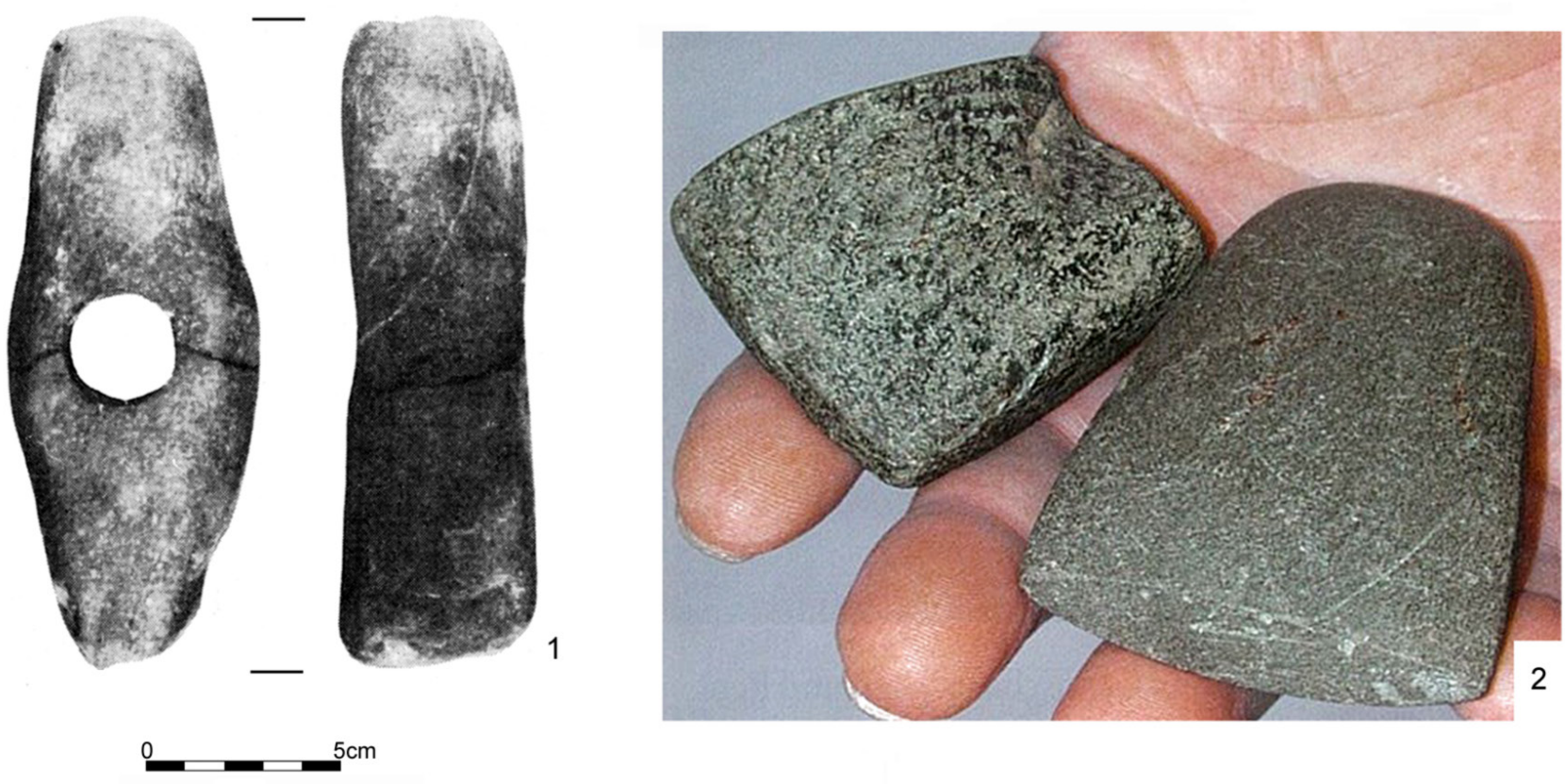

Fig. 7. Thunderstones from Germany missing the cutting edge: 1 - Mellenau. Fig. unscaled. After Schoknecht 1964, Fig. 181:d; 2 - Großgoltern. After Cosack 2004, Fig. unnumbered. Digitally processed by T. Kurasiński.

Likewise, in the collected materials, many copies show considerable damage. Not all of them can be explained by their prehistoric origins. Some may have arisen as a result of the "new use" of stone artefacts back in the Middle Ages. ${ }^{100}$

Widespread accounts of the scraping of ancient stone products in order to obtain healing powder seem to be a logical explanation for the secondary shearing and smoothing of the blades of Neolithic axes discovered in a field near Großgoltern (Lower Saxony, Germany), eventually obscuring their original function (Fig. 7:2). ${ }^{101}$ The axe from Mellenau (Mecklenburg, Germany) was also intentionally deprived of the cutting edge (Fig. 7:1). ${ }^{102}$ In the discussed context, attention is also drawn to the intentional clash of both surfaces of the Neolithic hammer-axe from the medieval Křivoklát castle in Czech Republic (Fig. 8:1) ${ }^{103}$ and the subsequent violation of the original form of specimens found within another Czech fortress, Kozí Hrádek (Fig. 8:2-4). ${ }^{104}$ Scratches are also noticeable on an axe from Železna Ruda in the Czech Republic (Fig. 8:5). They probably appeared only after the object

\footnotetext{
${ }^{100}$ Hložek et al. 2015, 274.

${ }^{101}$ Cosack 2004, 63; Sachße 2008, 237.

${ }^{102}$ Schoknecht 1964, 378, Fig. 181:d; Heidelk-Schacht 1983, 107, Fig. 17:a.

${ }^{103}$ Durdík 1997, 107.

${ }^{104}$ Hložek and Menšík 2009, 67. One of them also has secondary drilling traces. It cannot be ruled out that it is a failed product (Hložek and Menšík 2009, 71-72).
}

was already being used as a thunderstone. ${ }^{105}$ The use of powdered thunderstone may confirm several Neolithic artefacts found in medieval Lund (Sweden), which are characterised by damage difficult to explain - broken cutting edges or hollow pits (Fig. 9) ${ }^{106}$ Both ends of the specimen from Uppland (Sweden) were probably also damaged in order to obtain effective medicine. ${ }^{107}$ It may also be suggested by traces of scraping on the surface of some tools from Novgorod (Russia) (Fig. 10), ${ }^{108}$ although that can also be interpreted as the effect of simply sharpening metal tools. ${ }^{109}$ Secondary interference in the structure of Estonian specimens was also noticed. Sometimes only one side was rubbed, so that the blade became asymmetrical, as in the case of an axe found in Kõnnu. ${ }^{110}$ Over decades, collecting healing particles can almost completely destroy an object, reducing it to a small crumb or sliver, as in the case of one stone hammer from the Punkalaidun commune in southern Finland. ${ }^{111}$ In 1893, the pharmacist F. Prochno from Altmark reported that some of the items in his

\footnotetext{
${ }^{105}$ Menšík 2018, 30.

${ }^{106}$ Carelli 1996, 160, Fig. 4; 1997, Carelli 1997, 406, Fig. 6.

${ }^{107}$ Montelius 1906, 67, Fig. 99; Blinkenberg 1911, 91; Holtorf
} 2015,83 .

108 Tyanina 2018, 68, Fig. 6:f

${ }^{109}$ Musin et al. 2018, 31 .

110 Johanson 2009, 145. This targeted analysis of material from Western Norway did not fully confirm whether the observed damage was caused by the recommendations of folk medicine (Søyland 2017, 61, 81).

${ }^{111}$ Muhonen 2006, 8-9; Hukantaival 2019, 347. 


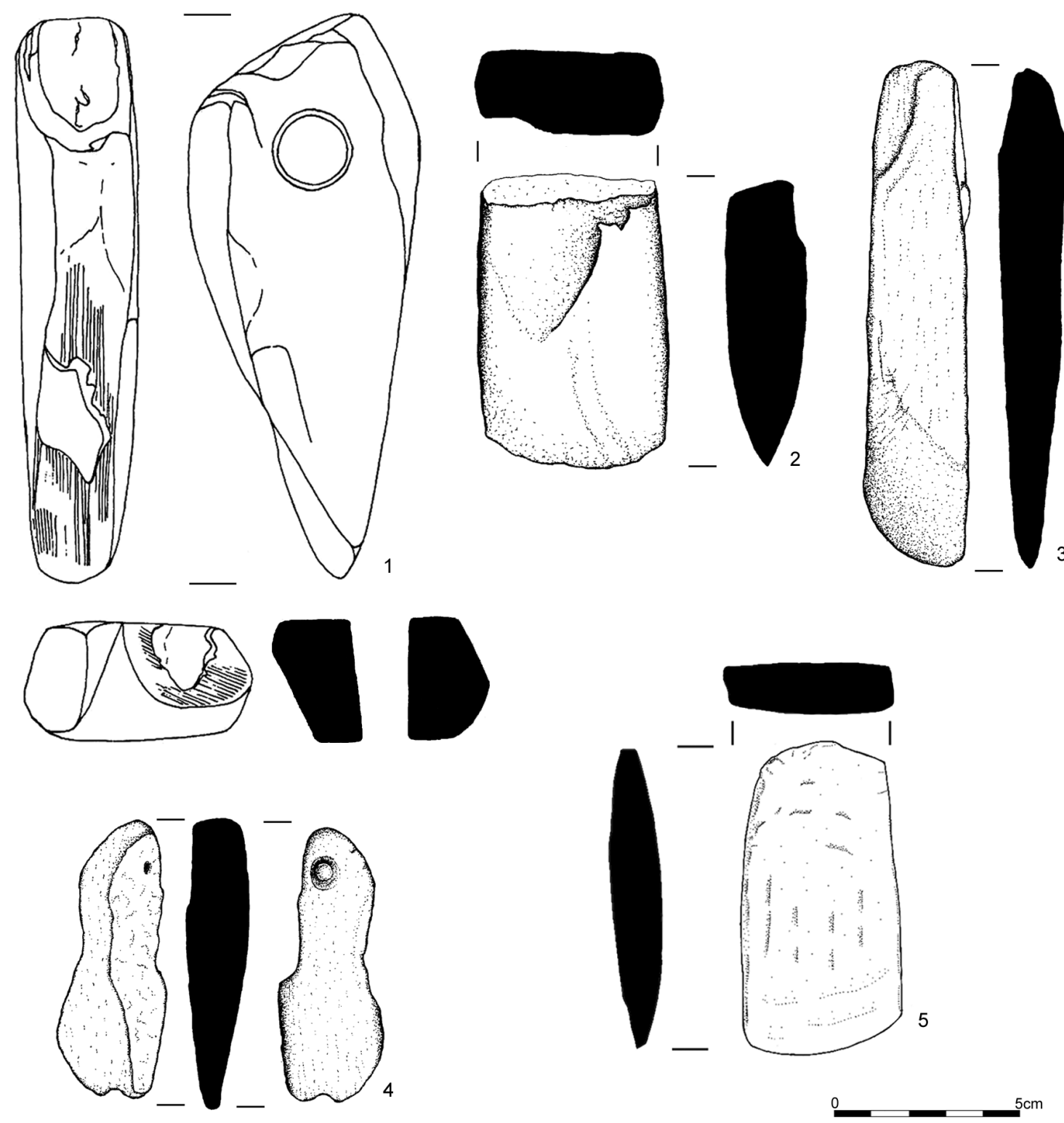

Fig. 8. Thunderstones with traces of reuse from the Czech Republic: 1 - Křivoklát. After Durdík 1997, Fig. 2:1; 2-4 - Kozí Hrádek. After Hložek and Menšík 2009, Figs. 6-8; 5 - Železná Ruda. After Menšík 2018, Fig. 2. Digitally processed by T. Kurasiński.

possession were so scraped that their original form was almost unrecognisable. ${ }^{112}$

An axe found in Pockau (Saxony, Germany) under the floor of a house dated to the second half of the $17^{\text {th }}$ century (next to the axe was a clay vessel with the same date) may be presumed evidence of "treatment trials', in which a key role was played by the hole of an axe. This axe was made from a larger, broken specimen (Fig. 11), indicated by irregular and superficial processing and a new hole in place of the previous, still partially visible one. ${ }^{113}$ This modification or repair, as important as it seems, could have taken place shortly before

\footnotetext{
${ }^{112}$ Ramminger 2007, 12.

${ }^{113}$ Geupel 1987, 2-3, Fig. 1:b.
}

the deposit (perhaps to restore the artefact's imagined magical properties). This observation would be important because it was believed that the hole for attaching the handle was created as a result of a lightning strike, hence the stone displayed greater magical power. ${ }^{114}$

It seems that the enhancement of the properties of thunderstones were various inscriptions, symbols and representations made in much later chronological and cultural realities. ${ }^{115}$ For these considerations, the runic magic-medical formula (lyfaetyio + ) visible on the axe of Vejle (Jutland, Denmark) is of particular importance

\footnotetext{
${ }^{114}$ See Sklenár 1999, 25; Hložek et al. 2015, 272.

${ }^{115}$ With examples, Kurasiński 2021, 37-41.
} 


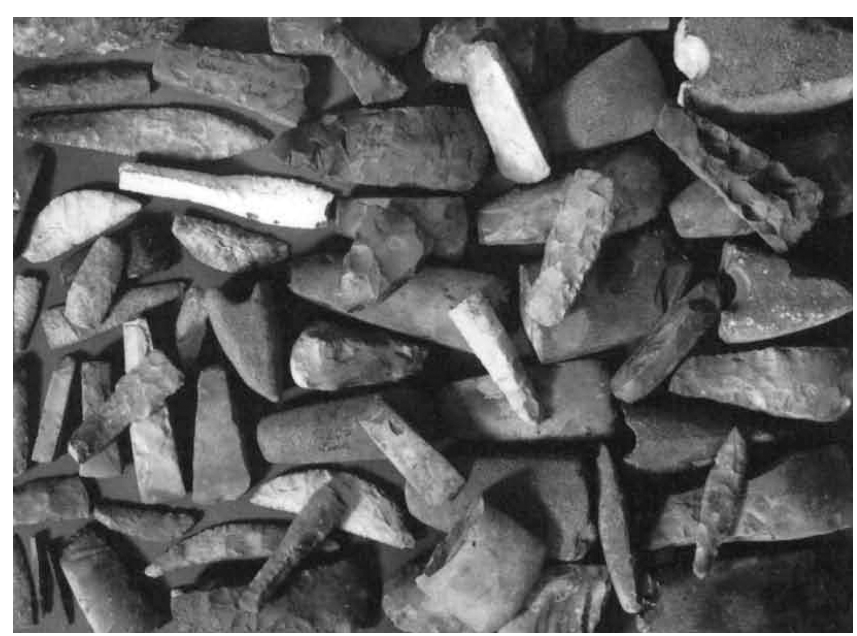

Fig. 9. Thunderstones from Lund (Sweden). Fig. unscaled. After Carelli 1996, Fig. 1.

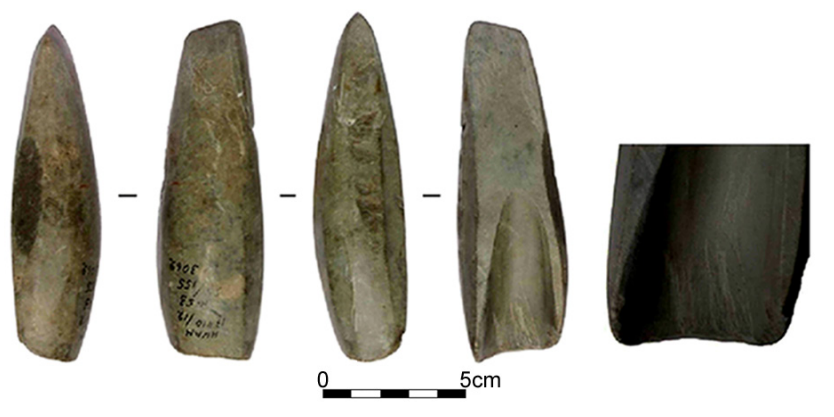

Fig. 10. Thunderstone from Novgorod (Russia) with engravings and alleged scraping traces. After Tyanina 2018, Fig. 6:f.

(Fig. 12). ${ }^{116}$ The carvings visible on the specimens from the medieval layers of Novgorod are also associated with healing magic (Fig. 10). ${ }^{117}$ The sign of the cross had the mentioned tool from Vijlen (Fig. 4).

\section{Conclusion}

In conclusion, it should be emphasised that in new cultural and chronological realities, the prehistoric stone objects referred to as 'thunderstones' were assigned various meanings, although their use was probably primarily dictated by the need to protect oneself and property against various types of disasters and misfortune. It is not surprising, then, that they have been used in folk medicine and healing magic, as well as personal, home, and household apotropaia. In view of constant threats, the overriding intention was to prevent the appearance of diseases and other plagues, and if

${ }^{116}$ Grünzweig 2004, 157, 159-160, Fig. 54; Quast 2011, 257258, Fig. 9:1; see also MacLeod and Mees 2006, 121.

${ }^{117}$ Musin et al. 2018, 30, Figs. 8:a-b and 9.

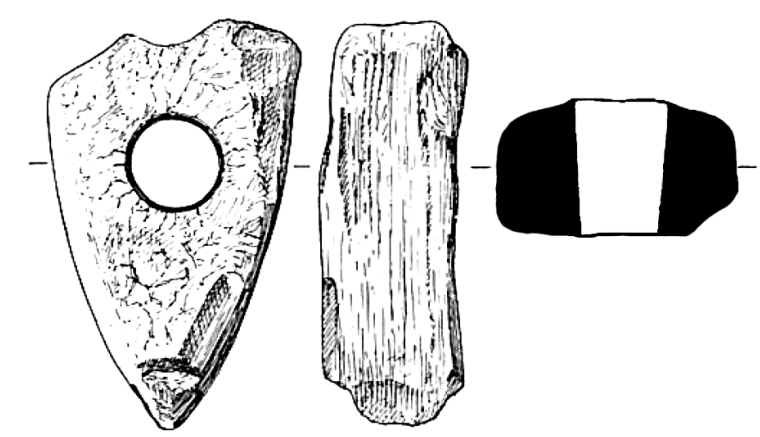

Fig. 11. Thunderstone from Pockau (Germany) with a secondary hole for attaching the handle. Fig. unscaled. After Geupel 1987, Fig. 1. Digitally processed by T. Kurasiński.

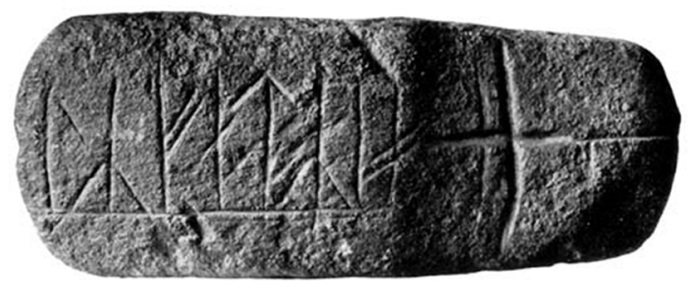

Fig. 12. Thunderstone from Vejle (Denmark) with a runic magic/ medical formula. After Quast 2011, Fig. 9:1. Digitally processed by T. Kurasiński.

they appeared anyway, to get rid of them by all possible means and methods. This was done through appropriate behaviours and ritual activities, including various methods and ways of using thunderstones. In light of the collected data, their role was on the one hand to prevent the harmful effects of the disease and the loss of fertility and harvest (preventive and prophylactic practices), and on the other hand to get rid of and neutralise misfortune once it occurred (rehabilitation and cleansing practices). In the first case, thunderstones could take the form of an amulet, ${ }^{118}$ and in the second, they could be used as a medicine applied in various forms and forms. In fact, it is difficult to make a strict distinction here, since 'apotropaic actions almost always associate with cleansers, transforming into them. However, the moment of such a transition is elusive. ${ }^{119}$ It

${ }^{118}$ Medical efficacy was attributed to polished and perforated axes attached to rosaries, as was the case in Brittany, France (Saintyves 1936,117$)$.

${ }^{119}$ Dynin 2013, 92. 
was often not realised that some treatments, especially massaging and rubbing an inefficient or sore part of the body, had a soothing effect, regardless of the belief in the supernatural properties attributed to the amulet. ${ }^{120}$

Trust in the magical (apotropaic) properties of thunderstones was probably related to the belief in the origin of these objects from outside the sphere of the tamed world. ${ }^{121}$ As we know, the 'untamed world' (orbis exterior) - an ambiguous and disturbing arena - appeared in the traditional perception of reality as a potential source of power, which, when properly used, made it possible to overcome crisis when routine measures failed. At the same time, the 'untamed world' brought with it a threat in the form of an anomie and the risk of bringing disaster. The zone located 'outside' thus shows the ability to update itself both as an 'ordering principle' and as an 'entropy principle', which could be manifested in the beneficial or destructive work of magical power. ${ }^{122}$ It is precisely because of the disordered and hybrid nature of the 'untamed world' that contact with objects originating there and the aura of strangeness connected with them must have evoked contradictory emotions, oscillating between fascination (fascinans) and fear (tremendum). ${ }^{123}$

From its 'supernatural' origin comes the kind of homeopathic power of the stone itself, the closed energy of which, having originated in lightning, can therefore be directed against lightning and other misfortunes. ${ }^{124}$ We are thus dealing with one of the two principles of J. G. Frazer's classical theory of magic (homoeopathic magic), according to which 'like causes like'. ${ }^{125}$ Frazer found a later addition to the formula of M. Mauss that 'like removes like in order to stimulate the opposite'. ${ }^{126}$ In mythical terms, it can be expressed as follows: if a thunder god annihilates evil (chthonic) forces with his weapons, then analogically, the use of a thunderstone for healing purposes prevents or fights the disease. ${ }^{127}$

However, it cannot be convincingly stated whether there were any criteria (e.g. circumstances of discovery, physical features) that would determine the specific application and attribution of functions to the artefacts in question, including a role in preventing diseases and relieving symptoms - it probably depended on immediate needs or local tradition. The same object could have various uses over the years - for example, a diorite hammer-axe found in the village of Štrampouch (Czech Republic) was initially placed in the ridge of the roof as a protection against lightning, then it was used to treat hernias in children, and finally to increase the milk yield of cows. ${ }^{128}$ We also know little about the temporal and spatial conditions of taking treatments with the use of thunderstones; however, we do know that sometimes attention was paid to the time of day. In turn, hanging thunderstones within pens or placing them in watering holes was intended to protect the space exposed to the intrusion of evil forces in the form of disease or other plague.

All this significantly hinders the identification of which particular specimens were used for medical purposes, although the captured features and preserved traces can be considered as a premise for a long and well-established tradition of the therapeutic usage of thunderstones, which is a pan-European phenomenon. As an attempt to introduce the discussed phenomenon, this article is intended to encourage further discussion on this interesting issue.
${ }^{120}$ García Castro 1988, 439.
${ }^{121}$ See Kajkowski 2020, 309.
${ }^{122}$ Zając 2003, 88-91.

${ }^{123}$ See Skóra and Kurasiński 2012, 205; Kurasiński et al. 2015,158 . The introduction of such objects into the 'tame world' posed a direct threat; hence their use required appropriate safeguards and special care. In the case of thunderstones, efforts were made to store them in secluded places and limit direct contact with them, sometimes completely refraining from touching them, and in extreme cases they were destroyed and buried (see Kurasiński 2021, 33).

${ }^{124}$ Cherici 1989, 374.

${ }^{125}$ Frazer 1971, 44-75; see Zimoń 2011, 169-170.

${ }^{126}$ Mauss 2001, 95.

\footnotetext{
${ }^{127}$ Cf. Jastrzębski 1996, 261-262.

${ }^{128}$ Sklenáŕ 1999, 57.
} 


\section{References}

Abramowicz A. 1979. Urny i ceraunie. Acta Archaeologica Lodziensia 27. Łódź.

Aguirre Sorondo A. 2013. El rayo y el trueno en Euskalerria / Lightnings and thunders: Protection elements. "Kobie. Antropología cultural" 17, 135-150.

Andree R. 1889. Etnographische Parallelen und Vergleichen. Neue Folge. Leipzig.

Barnaś-Baran E. 2018. Naturalne metody leczenia dzieci i dorostych w XIX w. w świetle rękopisu Stosława Laguny (1833-1900). “Annales Universitatis Mariae Curie-Skłodowska. Sectio J - Paedagogia-Psychologia” 31(2), 11-24.

Barner W. 1957. Von Kultäxten, Beilzauber und rituellem Bohren. "Die Kunde. N.F” 8(3-4), 175-186.

Bartels M. 1893. Beiträge zum Steinbeil-Aberglauben in Nord-Deutschland. "Verhandlungen der Berliner Gesellschaft für Anthropologie, Ethnologie und Urgeschichte" 1893, 558-564.

Beuker J. 1997. Donderstenen in het museum. "Waardeel: Drents historisch tijdschrift" 17(4), 20-24.

Biegeleisen H. 1929. Lecznictwo ludu polskiego. Kraków.

Blas Cortina M. Á. de, Maya González J. L. 1974. Hachas pulimentadas en castros asturianos. "Boletín del Real Instituto de Estudios Asturianos" 28(81), 199-216.

Blas Cortina M. Á. de, Villa Valdés Á. 2007. La presencia no accidental de un hacha de talón en un fondo de hogar en el castro del Chao Samartín (Grandas de Salime, Asturias). In: J. Celis Sánchez, G. Delibes de Castro, J. Fernández Manzano, L. A. Grau Lobo (eds.), El hallazgo leonés de Valdevimbre y los depósitos del Bronce Final Atlántico en la Península Ibérica. León, 280-289.

Blinkenberg Ch. 1911. The Thunderweapon in Religion and Folklore. A Study in Comparative Archaeology. Cambridge.

Boges Th. 1910. Aus der Heidenzeit des braunschweigischen Landes. Braunschweig.

Burić T. 2015. "Strilni kamen" s Baba lokve / "Thunder stone" from Baba lokve site. "Archaeologia Adriatica" 9(1), 351-364.

Burke P. 2009. Kultura ludowa we wczesnonowożytnej Europie. Warszawa.

Carelli P. 1996. Blixtar och dunder, magiska under. Om åskstenstraditionen och förekomsten av stenåldersfynd i medeltida kulturlager. "Fornvännnen" 91(3), 153-170.

Carelli P. 1997. Thunder and Lightning, Magical Miracles. On the Popular Myth of Thunderbolts and the Presence of Stone Age Artefacts in Medieval Deposits. In: H. Andersson, P. Carelli, L. Ersgård (eds.), Visions of the Past. Trends and Traditions in Swedish Medieval Archaeology. Lund Studies in Medieval Archaeology 19. Riksantikvarieämbetet Arkeologiska undersökningar Skrifter 24. Stockholm, 393-417.

Cartailhac É. 1878. L'Âge de pierre dans les souvenirs et superstitions populaires. Paris.

Chadwick A. M. 2012. Routine Magic, Mundane Ritual: Towards a Unified Notion of Depositional Practice. "Oxford Journal of Archaeology" 31(3), 283-315.

Cherici A. 1989. Keraunia. "Archeologia Classica" 41, 329-382.

Ciubotaru S. 2002-2003. Elemente magice legate de tratamentul hemoriniei. "Anuar de Lingvistică și Istorie Literară" 42-43, 197-202.

Cosack E. 2004. Als die Steinbeile noch vom Himmel fielen. "Archäologie in Deutschland" 2004(1), 62-63.

Domańska A. 2016. Metody leczenia chorób wśród ludu polskiego w XIX wieku. Próba bilansu. "Zeszyty Wiejskie" 22, 309-322.

Duffin Ch. J., Pymm R. 2015a. A Survey of Artificial Pharmaceutical 'Stones'-Part 1. "Pharmaceutical Historian" 45(1), 2-9.

Duffin Ch. J., Pymm R. 2015b. A Survey of Artificial Pharmaceutical 'Stones'-Part 2. "Pharmaceutical Historian" 45(2), 28-33.

Durdík T. 1997. "Hromový klín” z hradu Křivoklátu. "Sborník Kruhu přátel muzea hl. m. Prahy" 1997(1), 107-110.

Dynin V. I. 2013. O ponyatii apotropeya, ili oberega. "Vestnik Voronezhskogo gosudarstvennogo universiteta. Seriya: Istoriya. Politologiya. Sotsiologiya" 1, 90-94.

Eijk G. van 2007. De dondersteen van Uden. Een neolithische bijl uit een middeleeuwse waterput. "Westerheem: Het tijdschrift voor Nederlandse archeologie" 56(4), 208-216.

Ellis Davidson H. R. 1965. Thor's Hammer. "Folklore" 76(1), 1-15.

Evans J. 1897. The Stone Implements, Weapons and Ornaments of Great Britain. London, Bombay.

Farkaš M., Gregor M. 2016. K otázke niektorých kamenných brúsených nástrojov z Bratislavy-Devína. In: I. Bazovský (ed.), Zborník na pamiatku Magdy Pichlerovej. Zborník Slovenského národného múzea. Archeológia Supplementum 11. Bratislava, 35-43. 
Foster G. M. 1976. Disease Etiologies in Non-Western Medical Systems. "American Anthropologist. New Series" 78(4), 773-782.

Frazer J. G. 1971. Złota gałaź 1. Warszawa.

Fröhlich J. 1992. Hromové kliny v jižních Čechách. "Výběr z prací členů Historického klubu při Jihočeském muzeu v Českých Budějovicích” 29(4), 237-245.

García Castro J. A. 1988. Mitos y creencias de origen prehistórico: «Las Piedras de Rayo». "Espacio, Tiempo y Forma. Serie 1: Prehistoria" 1, 427-443.

Gazin-Schwartz A. 2001. Archaeology and Folklore of Material Culture, Ritual, and Everyday Life. "International Journal of Historical Archaeology" 5(4), 263-280.

Gazin-Schwartz A., Holtorf C. 2005. 'As long as ever I've known it ... 'On folklore and archaeology. In: A. GazinSchwartz, C. Holtorf (eds.), Archaeology and Folklore. London, New York, 2-23.

Geupel V. 1987. Ein Bauopfer aus Pockau, Kr. Marienberg. "Ausgrabungen und Funde" 32(1), 2-5.

Górny K. 1996. Czas i przestrzeń w magii leczniczej. "Literatura Ludowa" 40(2), 19-29.

Grønbeck I. A. 2016. En gave fra gudene? "Frá haug ok heiðni" 4, 19-22.

Grünzweig F. E. 2004. Runeninschriften auf Waffen: Inschriften vom 2. Jahrhundert n. Chr. bis ins Hochmittelalter. Wiener Studien zur Skandinavistik 11. Wien.

Hála J. 2016a. Alföldi adatok a „,mennykövek”-röl. In: J. Hála, Különös kövek, csodás csontok. Kilenc dolgozat a népi geológia köréböl. Rudabánya, 41-68.

Hála J. 2016b. Ásványokkal és közetekkel kapcsolatos néprajzi adatok a Börzsönyböl és környékéröl. In: J. Hála, Különös kövek, csodás csontok. Kilenc dolgozat a népi geológia köréböl. Rudabánya, 85-108.

Hall M. A. 2005. Burgh mentalities: a town-in-the-country case study of Perth, Scotland. In: K. Giles, C. Dyer (eds.), Town and Country in the Middle Ages: Contrasts, Contacts and Interconnections, 1100-1500. Leeds, 211-228.

Hammarstedt N. E. 1920. Svensk forntro och folksed i bild och ord. Stockholm.

Hammarstedt N. E. 1925. Donnerkeil. In: M. Ebert (ed.), Reallexikon der Vorgeschichte 2. Berlin, 444-448.

Heidelk-Schacht S. 1983. "Donnerkeile" aus dem Bezirk Neubrandenburg. "Ausgrabungen und Funde" 28(3), 105-109.

Helwing G. A. 1717. Lithographia Angerburgica. Regiomonti.

Hložek J., Menšík P. 2009. „Hromové klíny” z Koziho hrádku na Táborsku aneb „Účinné“ zajištěni hradu před přirodni pohromou, nebo starši pravěké sidlištěe. "Kuděj: Časopis pro kulturní dějiny” 1, 63-73.

Hložek J., Menšík P., Procházka M. 2015. Bauopfer im mittelalterlichen Böhmen. "Fines Transire" 24, 271-280.

Holtorf C. 2015. From Stonehenge to Las Vegas. Archaeology as Popular Culture. Walnut Creek, Lanham, New York, Toronto, Oxford.

Horoszkiewicz R. 1950. Toporki neolityczne w lecznictwie ludowym na Opolszczyźnie. "Z Otchłani Wieków" 19(9-10), 159-160.

Houlbrook C. 2019. 'The Stone Axe from Way Back': A Mutable Magical Object in Folklore and Fiction. "Folklore" 130(2), 192-202.

Hraše J. K. 1898. Hromové klíny aneb kameny. "Český lid” 7(1), 82-83.

Hukantaival S. 2016. "For a Witch Cannot Cross Such a Threshold!” Building Concealment Traditions in Finland c. 1200-1950. Archaeologia Medii Aevi Finlandiae 23. Turku.

Hukantaival S. 2019. Ukonvaajojen monet kasvot - Luokittelu- ja tulkintakysymyksiä. In: J. Harjula, V. Immonen, J. Ruohonen (eds.), Puukenkien kopinaa.Henrik Asplundin juhlakirja. Karhunhammas 19. Turku, 345-381.

Hutschemakers S. 2008. Vóór de veearts kwam...Volksdiergeneeskunde van weleer. Leiden.

Jaguś I. 2001. Lecznictwo ludowe w Polsce w XX wieku - czynniki i kierunek przemian. "Annales Universitatis Mariae Curie-Skłodowska. Sectio I - Philosophia-Sociologia" 26(13). 175-187.

Jastrzębski J. 1996. Z badań nad ludowym lecznictwem zwierząt w pótnocno-wschodniej Polsce w XIX i XX wieku. "Studia Łomżyńskie" 6, 255-269.

Jeszke J. 1993. Lecznictwo ludowe w Wielkopolsce w XIX i XX wieku. Czynniki i kierunki przemian. "Medycyna Nowożytna: Studia nad historią medycyny" 1(1), 83-120.

Johanson K. 2009. The Changing Meaning of 'Thunderbolts'. "Folklore. Electronic Journal of Folklore" 42, 129-174.

Johanson K. 2018. Missing Interpretations. Natural and Residual Finds in Estonian Archaeological Collections. Dissertationes Archaeologiae Universitatis Tartuensis 8. Tartu.

Kajkowski K. 2020. Między sfera niebiańska a zaświatami. Rola artefaktów pradziejowych w kulturze wczesnośredniowiecznych Pomorzan. In: A. Kasprzak, A. Kuczkowski, M. Krzepkowski (eds.), Archaeologia Pomoranica Musealia. Studia z okazji 80. urodzin Ignacego Skrzypka. Koszalin, 301-332. 
Kaufmann D. 1936. Vorgeschichtliche Steinwerkzeuge im Volksglauben. "Der Spatenforscher" 1(4), 29-35.

Kędzierzawski W. 2009. Codzienność jako kategoria antropologiczna w perspektywie historii kultury. Opole.

Kharuzin N. N. 1894. Iz materialov, sobrannykh sredi krest'yan Pudozhskogo uyezda Olonetskoy gubernii. "Olonetskiy sbornik. Materialy dlya istorii, geografii, statistiki i etnografii Olonetskogo kraya" 3, 302-346.

Kieckhefer R. 2001. Magia w średniowieczu. Kraków.

Klecanda J. 1901. Hromové kameny (předhistorické mlaty) v XV. a XVI věku. “Český lid” 10(3), 214-215.

Kłonkowska A. M. 2006. Myślenie mityczne, magiczne i racjonalne. In: M. Gajewska, B. Lange, D. Nawrot (eds.), Między filozofia a przyrodoznawstwem. Księga jubileuszowa dedykowana Profesorowi Ludwikowi Kostro. Gdańsk, 231-244.

Knight M. G., Boughton D., Wilkinson R. E. 2019. Objects of the Past in the Past. In: M. G. Knight, D. Boughton, R. E. Wilkinson (eds.), Objects of the Past in the Past Investigating the Significance of Earlier Artefacts in Later Contexts. Oxford, 1-18.

Koudelka F. 1882. Die Donnersteine als Medicin bei den mährischen Slaven. "Mittheilungen der Anthropologischen Gesellschaft in Wien" 12 (NF 2), 159-160.

Kunnas-Pusa L. 2016. Tärvellyt ja kaaputetut - Kivikautiset irtolöydöt Jaakkiman pitäjästä ja kivikauden esineiden keräily 1800-1900-lukujen vaihteessa. "Muinaistutki" 4, 2-17.

Kurasiński T. 2021. Kamienie zrodzone z pioruna. O nietypowej formie recyklingu $w$ średniowieczu i czasach nowożytnych. "Przegląd Archeologiczny" 69, 5-62.

Kurasiński T. forthcoming. Proshloye sokhraneno v kamne. O neobychnom oruzhii srednevekov'ya i sovremennosti.

Kurasiński T., Purowski T., Skóra K. 2015. Reuse of Prehistoric Items in the Early Middle Ages: The Example of the Cemetery in Lubień, Voivodeship Łódź. "Archaeologia Polona" 48(2010), 139-165.

Kurasiński T., Skóra K. 2020. From the past into the future - archaica as a research problem (on the basis of medieval and modern period finds from Central-Eastern Europe) / Z przeszłości w przyszłość - archaika jako problem badawczy (na podstawie średniowiecznych i nowożytnych materiatów z Europy Środkowo-Wschodniej). In: M. Bogucki, A. Dymowski, G. Śnieżko (eds.), Silvers of the Antiquity. The Use of Ancient Coins in Central, Eastern and Northern Europe in the Medieval and Modern Periods / Okruchy starożytności. Użytkowanie monet antycznych w Europie Środkowej, Wschodniej i Pótnocnej $w$ średniowieczu $i$ w okresie nowożytnym. Warszawa, 301-366.

Kurtz H. 1928. Eine Steinaxt der ältesten Eisenzeit aus Lugnian Kreis Oppeln. "Oppelner Heimatblatt" 4(6), 1-2.

Labatt M. A. 2018. Turning an Axe on Its Head. A Journal of Decorative Arts. "Design History and Material Culture" $25(2), 160-175$.

Libera Z. 2003. Znachor w tradycjach ludowych i popularnych XIX-XX wieku. Wrocław.

Libera Z. 2014. Semiotyka medycyny we wczesnej nowożytności a etnosemiotyka w etnomedycynie XIX-XX wieku. "Rocznik Antropologii Historii" 4(1), 57-91.

Lovisato D. 1878. Di alcune azze, scalpelli, martelli e ciottoli dell'epoca della pietra trovati nella Provincia di Catanzaro. "Bollettino della Societa Adriatica di Scienze Naturali in Triste" 3, 475-505.

Łapo J. M. 2008. Ludowa wizja przeszłości Mazur. Stanowiska archeologiczne i miejsca o znaczeniu historycznym na dawnym pograniczu galindzko-jaćwieskim w świadomości Mazurów (XVI w. - I połowa XX w.). Olsztyn.

MacLeod M., Mees B. 2006. Runic Amulets and Magic Objects. Woodbridge.

Mainka-Mehling A. 2009. Hinweise auf frühmittelalterlichen „Aberglauben”? Eine Kritik am Beispiel der Altstücke im Grab. "Ethnographisch-Archäologische Zeitschrift" 50(1-2), 131-138.

Malinowski B. 1990, Mit, magia, religia. Dzieła 7. Warszawa.

Marczewska M. 2012. Ja cię zamawiam, ja cię wypędzam... Choroba. Studium językowo-kulturowe. Kielce.

Marczewska M. 2019. Choroba - obraz utrwalony w tekstach folkloru polskiego. In: S. Konarska-Zimnicka, L. Kostuch, B. Wojciechowska (eds.), Medicina antiqua, mediaevalis et moderna. Historia - filozofia - religia. Kielce, 343-356.

Mauss M. 2001. Socjologia i antropologia. Warszawa.

Mehling A. 1998. Archaika als Beigaben. Studien an merowingerzeitlichen Gräberfeldern. Rahden/Westfalen.

Meinecke M. 2014. Cerauniae - Donnerkeile. In: U. Veit, M. Wöhrl (eds.), Donnerkeil - Opfermesser - Thrängefäß. Die archäologischen Objekte aus der Sammlung der Leipziger Apothekerfamilie Linck (1670-1807) im Naturalienkabinett Waldenburg (Sachsen). Leipzig, 49-51.

Menšík P. 2018. Nový nález „,hromového klínu“ ze Železné Rudy, okr. Klatovy. "Archeologie západních Čech” 9(1), 29-31.

Merrifield R. 1987. The Archaeology of Ritual and Magic. London. 
Montelius O. 1906. Kulturgeschichte Schwedens von den ältesten Zeiten bis zum elften Jahrhundert nach Christus. Leipzig.

Moszyński K. 1967. Kultura ludowa Stowian 2: Kultura duchowa 1. Warszawa.

Muhonen T. 2006. Kolme ajallista näkökulmaa ukonvaajoihin. Kivikauden kiviesineet myöhempien aikojen kuriositeetteina. "Kuriositeettikabi.net" 2006(3), 1-23.

Musiatewicz J. 2003. Święte stowa i "biotoki". Eklektyczny charakter lecznictwa ludowego. In: Ł. Smyrski, M. Zowczak (eds.), Podole i Wotyń. Szkice etnograficzne. Warszawa, 175-187.

Musin A. E., Żeltowa M. N., Tarabardina O., Tianina E. A. 2018. Kamienne artefakty z epoki neolitu i wczesnej epoki żelaza jako amulety średniowiecznego Nowogrodu. In: S. Rosik, S. Jędrzejewska, K. Kollinger (eds.), Hierofanie, wierzenia, obrzędy... Kultura symboliczna $w$ średniowieczu między pogaństwem a chrześcijaństwem. Materiały V Kongresu Mediewistów Polskich 2. Rzeszów, 13-41.

Ofrim A. 2019. Attitudes Towards Prehistoric Objects in Romanian Folk Culture (19 th $^{\text {20 }} 0^{\text {th }}$ Century). "Swedish Journal of Romanian Studies" 2(1), 92-109.

Olbrich K. 1987. Donnerkeil. In: H. Bächtold-Stäubli, E. Hoffmann-Krayer (eds.), Handwörterbuch des deutschen Aberglaubens 2. Berlin, New York, 325-331.

Palliardi J. 1889. Zažehnávání hromovým kamenem. "Časopis Vlastivědného spolku muzejního v Olomouci" 6(22), 87.

Pedrosa J. M. 2009. Jussieu, Feijoo y las piedras del rayo, o la razón moderna frente a la vieja superstición. "Revista Murciana de Antropología" 16, 245-270.

Penkala-Gawęcka D. 1994a. Antropologiczne spojrzenie na chorobę jako zjawisko kulturowe. "Medycyna Nowożytna: Studia nad historią medycyny" 1(2), 5-16.

Penkala-Gawęcka D. 1994b. Antropologia medyczna a etnofarmakologia. "Lud" 77, 13-21.

Penkala-Gawęcka D. 1995. Medycyna ludowa i komplementarna w polskich badaniach etnologicznych. "Lud" 78, 169-191.

Penney S. H. 1976. Axes, Arrowheads and Other Antiquities in Irish Folklore. "Ulster Folklife" 22, 70-75.

Plessingerová A., Vařeka P. 1999. Bouře, hromový kámen v lidových představách, víre a obyčejích. In: L. Tarcalová (ed.), Kult a živly. Sborník př́spěvků z konference karpatologické komise pro lidové obyčeje MKKK konané ve Vsetině v roce 1999. Uherské Hradiště, 207-213.

Pokrovskiy F. V. 1899. Arkheologicheskaya karta Kovenskoy gubernii. Vil'na.

Pymm R. 2017. 'Serpent stones': myth and medical application. In: C. J. Duffin, C. Gardner-Thorpe, R. T. J. Moody (eds.), Geology and Medicine: Historical Connections. London, 163-180.

Pymm R. 2020. Snakestones in Early Modern Medicine and Society. "Pharmaceutical Historian" 50(4), 129-145.

Quast D. 2011. Ein Steinbeil mit magischer Inschrift aus der Sammlung des Prinzen Christian August von Waldeck. "Archäologisches Korrespondenzblatt" 41(2), 249-261.

Quintía Pereira R. 2009. A pedra da pezoña e outras pedras sandadoras da cultura popular galega. Grupo de Estudos Etnográficos Serpe Bichoca. http://www.galiciaencantada.com/archivos/docs/1555_Apedradapezo\%C3\%B1aeoutraspedrassandadorasdaculturapopulargalega.pdf. Available online: 15.04.2020.

Rajewski M. 2006. Antropologia i archeologia: wybrane problemy wspótpracy. In: W. Kozak-Zychman, J. Gurba (eds.), Rola i znaczenie nauk pomocniczych archeologii. Lublin, 81-99.

Ramminger B. 2007. Blitzschutz und Fruchtbarkeitsspender: noch einmal zu den „Donnerkeilen”. "Denkmalpflege und Kulturgeschichte" 2007(4), 11-13.

Rapan Papeša A. 2020. Magic or Practicality? "Antiquities” in Avar Period Graves in Eastern Croatia. In: S. Krznar, T. Sekelj Ivančan, J. Belaj, T. Tkalčec (eds.), Life and Death inMedieval and Early Modern Times. Proceedings of the $5^{\text {th }}$ International Scientific Conference of Mediaeval Archaeology of the Institute of Archaeology Zagreb, $6^{\text {th }}$ and $7^{\text {th }}$ June 2018. Zagreb, 17-31.

Reitinger J. 1976. "Donnerkeile” aus Oberösterreich und Salzburg. "Archaeologia Austriaca" 13-14, 511-546.

Ribon P. 1993. Pierres qui guérissent (eaux, animaux, végétaux, divinités). Lyon.

Rúa Aller F. J., García Armesto M. J. 2010. Usos y creencias de las piedras de rayo de León. "Revista de Folklore" 344, 61-68.

Rustoiu A. 2015a. Magic and Memory: Prehistoric and Roman "Antiquities": Avar Period Graves from the Carpathian Basin. "Transylvanian Review" 24, Supplement 2, 247-263.

Rustoiu A. 2015b. Shooting the Evil. "Scythian" Arrowheads in Avar Age Graves from the Carpathian Basin. In: C. Cosma (ed.), Warriors, Weapons, and Harness from the $5^{\text {th }}-10^{\text {th }}$ Centuries in the Carpathian Basin. Cluj-Napoca, 89-106. 
Sachße C. 2006. Donnerkeile in der Apotheke. "Deutsche Apothekenmuseum" 31(1), 5.

Sachße C. 2008. Mit der Streitaxt gegen die Gelbsucht? Archaeologica als Arzneimittel in historischer Zeit. In: F. Falkenstein, S. Schade-Lindig, A. Zeeb-Lanz (eds.), Kumpf, Kalotte, Pfeilschaftglätter. Zwei Leben für die Archäologie. Gedenkschrift für Annemarie Häußer und Helmut Spatz. Internationale Archäologie - Studia honoraria 27. Rahden/Westf., 227-244.

Saintyves P. 1936. Pierres magiques: Bétyles, Haches-Amulettes et Pierres de Foudre. Traditions savantes et Traditions populaires. Paris.

Schoknecht U. 1964. Kurze Fundberichte 1963. Bezirk Neubrandenburg. "Bodendenkmalpflege in Mecklenburg" 1964, 353-389.

Sedova M. V. 1957. Amulet iz drevnego Novgoroda. "Sovetskaya arkheologia" 1957(4), 166-167.

Seyfahrt C. 1913. Aberglaube und Zauberei in der Volksmedizin Sachsens. Ein Beitrag zur Volkskunde des Königsreichs Sachsen. Leipzig.

Sheridan A., Pailler Y., Pétrequin P., Errera M. 2011. Old Friends, New Friends, a Long-lost Friend and False Friends: Tales from Project JADE. In: V. Davis, M. Edmonds (eds.), Stone Axe Studies 3. Oxford, 411-426.

Shevelev V. V. 2005. Gromovye strely” proroka Il'ia. Étnograficheskie realii. "Zhivaia starina” 1, 2-3.

Sklenář K. 1999. Hromové klíny a hrnce trpasliki̊. Z pokladnice české folklorni archeology. Praha.

Skóra K., Kurasiński T. 2012 Nietypowe przedmioty w wyposażeniu dwóch pochówków z cmentarzyska wczesnośredniowiecznego w Radomiu, st. 4. "Światowit" 9(L)/B, 193-212.

Skutil J. 1932. Dva přispěvky k československému folkloru prehistorickému. “Český lid” 32, 35-52.

Søvsø M., Søvsø M. H., Siggaard A. L. 2016. Om hugorme, dyrekranier og tordensten - bygningsofre og andre skikke med dybe rødder i folketroen. "By Marsk og Geest" 28, 57-89.

Søyland K. 2017. Toresteinar. Ei undersøking av utbreiinga av eldre gjenstander av stein, sekundcert deponert i jernalderkontekstar i Vest-Noreg. Bergen. http://bora.uib.no/handle/1956/17518. Available online 10.04.2020.

Stein R. L., Stein Ph. L. 2010. The Anthropology of Religion, Magic and Witchcraft. London, New York.

Swienko H. 1981. Religia i religie. Warszawa.

Szczepanik P. 2016. Choroba jako kara za wystapienie przeciw bogom. Przyktady z przedchrześcijańskiej Stowiańszczyzny. In: E. Nowina-Sroczyńska, S. Latocha, T. Siemiński (eds.), Oblicza choroby w czasach płynnej nowoczesności. Bytów, Łódź, 24-35.

Szczepański S. 2010. Kamień i skała w mitologii, wierzeniach i obyczajowości ludów indoeuropejskich. In: R. Klimek, S. Szczepański (eds.), Kamienie w historii, kulturze i religii. Olsztyn, 7-23.

Šimek F. 1909. O hromovém kameni. "Český lid" 18, 458-459.

Šimek M. 2010. ,Kamena strela” u srednjovjekovnoj utvrdi?. “Zbornik Soboškega muzea” 15,135-149.

Toeppen M. 1867. Aberglauben aus Masuren mit einem Anhange, enthaltend: Masurische Sagen und Mährchen. Danzig.

Tolstoy N. I. 1995. Gromovaya strela. In: N. I. Tolstoy (ed.), Slavyanskie drevnosti 1. Moskva, 561-563.

Tyanina E. A. 2018. K voprosu o kul te Peruna v Novgorodskoy zemle (po materialam arkheologicheskogo issledovaniya Novgoroda). "Colloquia Russica" 1(8), 59-72.

Ungerman Š. 2009. Archaika in den frühmittelalterlichen Gräbern in Mähren. In: P. Maříková Vlčková, J. Mynářová, M. Tomášek (eds.), My Things changed Things. Social Development and Cultural Exchange in Prehistory, Antiquity, and the Middle Ages. Prague, 224-256.

Vasks A. 2003. The Symbolism of Stone Work-axes (Based on Material from the Daugava Basin). "Archaeologia Lituana" 4, 27-32.

Verhart L. 2015. Vuurstenen werktuigen. In: T. Derks, B. de Fraiture (eds.), Een Romeins heiligdom en een vroegmiddeleeuws grafveld bij Buchten (L). Verslag van een archeologisch noodonderzoek (1976). Amersfoort, 83-86.

Verhart L. 2016. Vondsten, vindplaatsen en verhalen: geneeskrachtige bijlen. "De Maasgouw" 135, 6-10.

Verhart L., Creemers G., Dreesen R., Goemaere E. 2021. Een donderbijl tussen de panlatten: een hamerbijl van het Muntendam-type I met een bijzonder verhaal (Soerendonk, gemeente Cranendonck, prov. Noord-Brabant, Nederland). "LUNULA. Archaeologia protohistorica" 24, 7-11.

Walęciuk-Dejneka B. 2005. Magiczne sposoby leczenia w tradycyjnej medycynie ludowej. Symbolika stów i gestów w aktach zażegnywania, zaklinania i zamawiania choroby. In: E. Łoch, G. Wallner (eds.), Między literatura a medycyna. Lublin, 67-76.

Waszk B. 2014. Lithoglyphi artefacti-Gemachte Formen oder Bildsteine. In: U. Veit, M. Wöhrl (eds.), Donnerkeil - Opfermesser - Thrängefäß. Die archäologischen Objekte aus der Sammlung der Leipziger Apothekerfamilie Linck (1670-1807) im Naturalienkabinett Waldenburg (Sachsen). Leipzig, 41-43. 
Watte J.-P., Jullien M. 2007. Un biface employe comme "ceraunie" ou "pierre de foudre" a Livet-sur-Authou (Eure). "Haute-Normandie Archéologique" 12, 5-8.

Wdowiak L., Wysokiński P. 2013. Piorunowe strzałki, grzmoty i gromy w medycynie ludowej na ziemiach polskich w okresie rozbiorów. In: M. Z. Felsmann, J. Szarek, M. Felsmann (eds.), Dawna medycyna i weterynaria. Środowisko a czlowiek. Chełmno, 519-545.

Wójtowicz M. 2012. Magiczne funkcje liczby trzy w medycynie ludowej. “Acta Humana” 3(1), 111-122.

Zając P. 2003. „Nadprzyrodzone” w kulturze ludowej. In: E. Przybył (ed.), Nadprzyrodzone. Kraków, 85-98.

Zimoń H. 2011. Terminy ,, magia” i ,,czarownictwo” w świetle badań etnologicznych i religioznawczych. "Roczniki Teologii Fundamentalnej i Religiologii" 3(58), 167-197. 